Revista Científica do Instituto Agronomico, Campinas

\title{
PIMENTEIRA-DO-REINO: PRODUTIVIDADE SEGUNDO O TIPO DE MUDA (')
}

Mário Cardoso, Seção de Plantas Tropicais, RuI RIBetro dos Santos, Estação Experimental de Pariqueraçu, e Tosho IgUe, Sę̧āo de Técnica Experimental e Cólculo, Instituto Agronômico

Botanicamente, dois tipos de ramos são encontrados na pimenteira-do-reino (Piper nigrum L.) : ortotrópicos e plagiotrópicos. Os primeiros, considerados ramos principais, têm crescimento vertical e suportam os ramos produtivos da pimenteira-do-reino, formando, por assim dizer, o esqueleto da planta. Já os plagiotrópicos, considerados secundários, constituem os ramos produtivos da pimenteira, com crescimento horizontal e aparecendo em grande número. Tradicionalmente, a propagação vegetativa dessa planta é feita a partir de estacas oriundas de ramos ortotrópicos. A utilização, esporádica, dos plagiotrópicos dá origem a plantas de porte baixo, isto é, seu desenvolvimento se verifica mais no sentido horizontal do que no vertical. Entretanto, como a formação de novas pimenteiras a partir desse tipo de ramos é muito mais fácil, pela sua abundância em uma única planta, fizeram-se observações sobre a sua produtividade em comparação com plantas oriundas dos ramos ortotrópicos. Sobre o assunto não foram encontradas referências bibliográficas.

Material e Método: De pimenteiras adultas, foram retiradas estacas de ramos ortotrópicos e plagiotrópicos. Para o enraizamento, utilizaram-se sacos plásticos, cheios com terra, e nas dimensões de $0,30 \mathrm{~m}$ de altura e $0,10 \mathrm{~m}$ de diâmetro, dispostos em ripado, na Estação Experimental do Instituto Agronômico em Pariqueraçu. De cada um dos dois tipos de mudas, foram selecionados, para plantio em lugar definitivo, 45 laminados. Após permanência de quatro meses no ripado, as mudas foram transplantadas no campo em fevereiro de 1974. Mourōes de $2,50 \mathrm{~m}$ de altura foram utilizados como tutores para as mudas oriundas de ramos ortotrópicos, e 
de $1,25 \mathrm{~m}$ para mudas provenientes de ramos plagiotrópicos (Fig. 1). Adubações e tratamento fitossanitário foram feitos para mais rápido desenvolvimento das plantas. O delineamento estatístico foi de blocos ao acaso, nove repetições e cinco plantas por parcela.

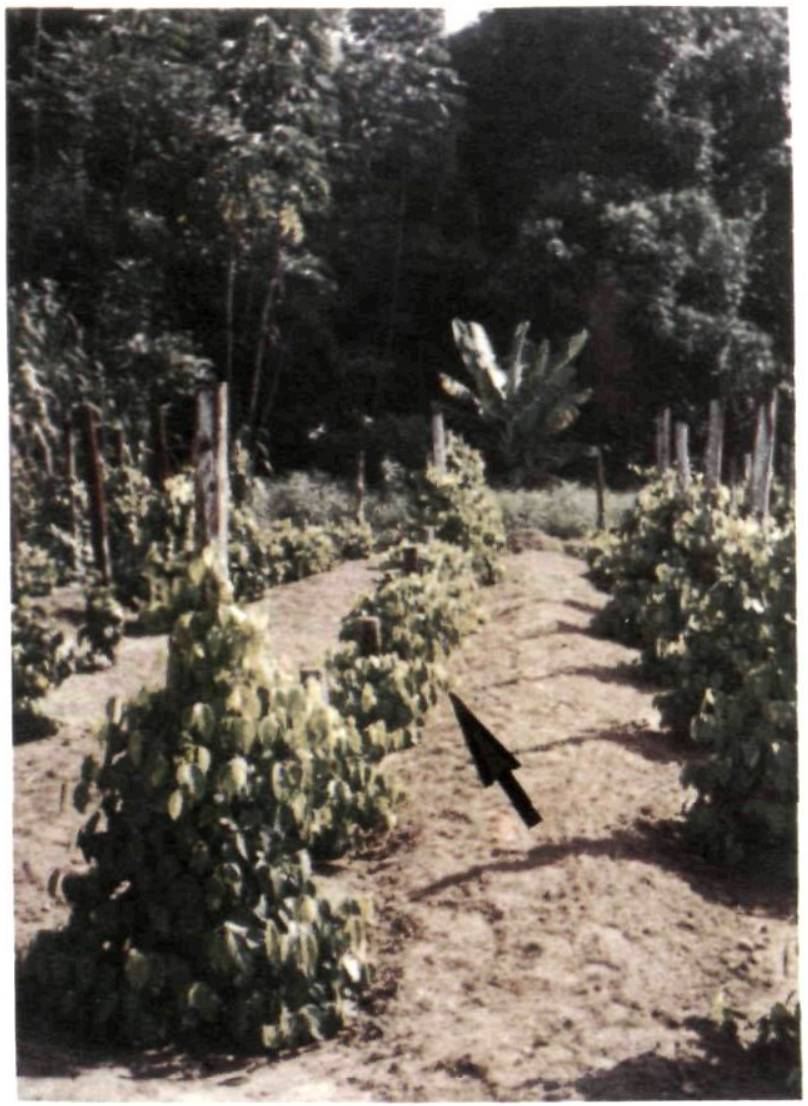

Figura 1. - Mudas de pimenteira-do-reino-oriunda de ramos plagiotrópicos. Estaçāo Experimental de Pariqueraçu (Foto do primeiro autor).

Resultados e Conclusões:

a) Formação de mudas. A facilidade no enraizamento de estacas oriundas de ramos plagiotrópicos, bem como na formação das plantas no campo, evidenciam a viabilidade no uso mais freqüen- te desse material para a multiplicação da pimenteira-do-reino.

b) Produtividade. No quadro 1, encontram-se as produções das pimenteiras a partir dos dois tipos de mudas. Pela análise dos dados, verificou-se que as produ- 
옹

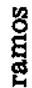

ชั

总

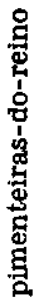

$\stackrel{8}{8}$

苞

政

蛋

of 8

索

द्व

a

.

若

品

递害

1 is

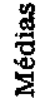

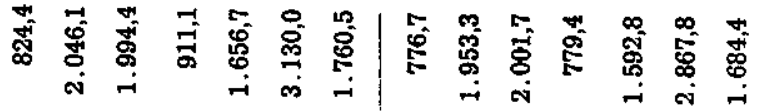

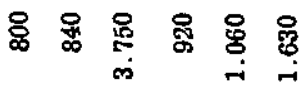

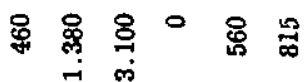

융 옹 융 8 운 웅

암 怘 怘

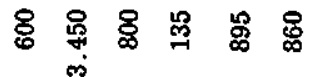

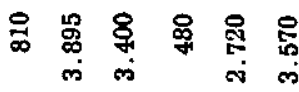

a

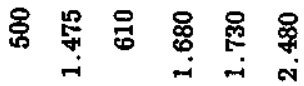

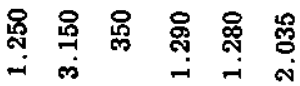

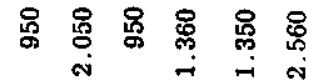

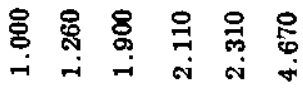

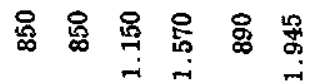

융용 \&

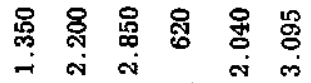

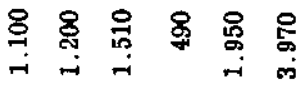

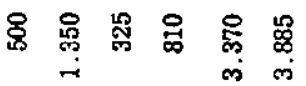

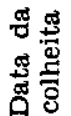

₹

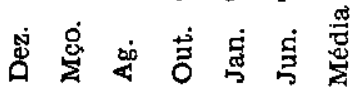

₹

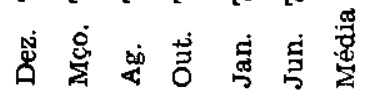


ções médias de dezembro/1977, no caso de plantas obtidas de ramos plagiotrópicos, foram inferiores àquelas obtidas em março/ 1978, janeiro/1979 e junho/1979 e, no caso de plantas obtidas de ramos ortotrópicos, foram inferio- res às de março/1978, agosto/1978 e junho/1979. Entre as demais épocas não houve diferenças significativas. Em média, as produções desses dois tipos de mudas não apresentaram diferenças significativas.

PEPPER: YIELD IN RELATION TO THE ORIGIN OF THE CUTTINGS

\section{SUMMARX}

An experiment was carried out at the Experiment Station located in Pariqueraçu, State of São Paulo, aiming to study comparatively the yield capacity of pepper when the plants were originated from cuttings obtained from plagiotropic and ortotropic branches.

For the building up of the plants the cuttings were taken from adult healthy plants. Forty five rooted cuttings of each type were planted in the field, in February 1974.

The results showed that the yield of seasoned fruits is equivalent in both types of plants: originated from plagiotropic and ortotropic branches. 